\title{
Belphégor
}

\section{Walid El Hamamsy and Soliman Mounira (Eds). Popular Culture in the Middle East and North Africa. A Postcolonial Outlook}

\section{Vittorio Frigerio}

\section{(2) OpenEdition \\ 1 Journals}

Electronic version

URL: http://journals.openedition.org/belphegor/568

DOI: 10.4000/belphegor.568

ISSN: 1499-7185

Publisher

LPCM

\section{Electronic reference}

Vittorio Frigerio, «Walid El Hamamsy and Soliman Mounira (Eds). Popular Culture in the Middle East and North Africa. A Postcolonial Outlook », Belphégor [Online], 13-1 | 2015, Online since 09 May 2015,

connection on 22 September 2020. URL : http://journals.openedition.org/belphegor/568 ; DOI : https://doi.org/10.4000/belphegor.568

This text was automatically generated on 22 September 2020.

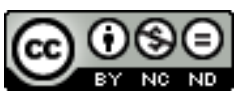

Belphégor est mis à disposition selon les termes de la Licence Creative Commons Attribution - Pas d'Utilisation Commerciale - Pas de Modification 4.0 International. 


\title{
Walid El Hamamsy and Soliman Mounira (Eds). Popular Culture in the Middle East and North Africa. A Postcolonial Outlook
}

\author{
Vittorio Frigerio
}

\section{REFERENCES}

El Hamamsy, Walid and Mounira Soliman (Eds). Popular Culture in the Middle East and North Africa. A Postcolonial Outlook. New York and London : Routledge Research in Postcolonial Literatures, 2013. 281 p. ISBN : 978-0-415-50972-5 
1 Popular culture started as a peculiarly western phenomenon. Its study therefore has been traditionally, and quite understandably, focused on works originating within what could be loosely defined as the First World : North America and Europe primarily. Critical theory has also been chiefly concerned with understanding the implications of these works within these particular cultural parameters. This collection of fifteen articles, divided in five thematic sections, attempts to open new ground by paying attention to contemporary manifestations of popular culture, in its many embodiments, in a region where it has not yet been widely considered. In their Introduction, the Editors make very clear their intention to put into question the notion itself of popular culture, both in

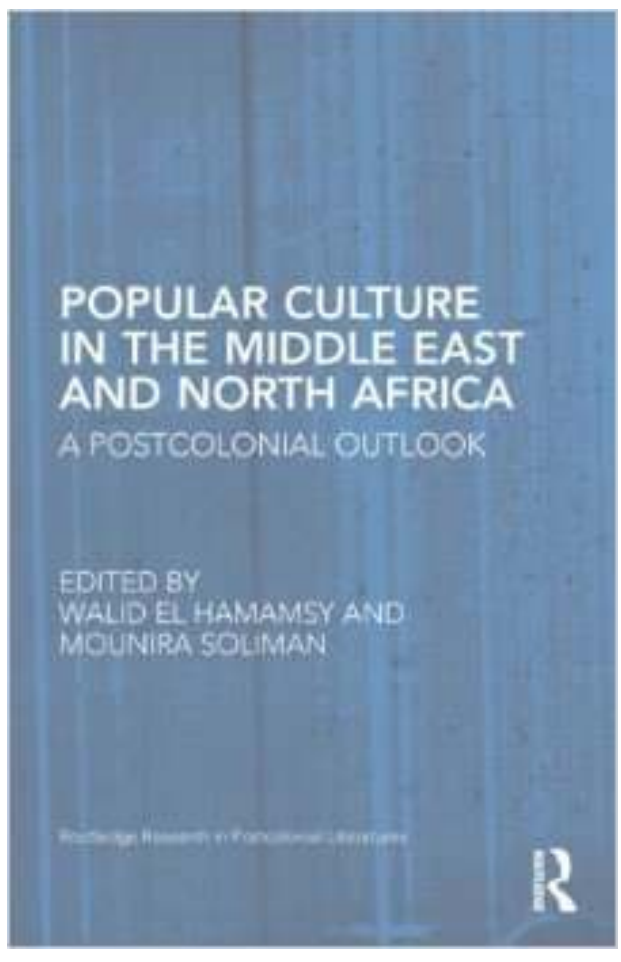
terms of its nature as a western cultural import and in its actual practice, which widely contradicts the presumed air-tight separation of high and low culture. Their goal goes even further, as they call for the creation of an autochthonous school of popular criticism, independent of western theories and methods.

2 The proposed definition of mass culture advanced in the Introduction is that of a supposedly "true voice of the people", that seeps up from in between the cracks of the dominant cultural forms. Indeed, the authors state : "This book looks at popular culture in the Middle East and North Africa as a form of cultural resistance against different forms of global and local domination"(7). In keeping with this view, each section is seen as a means to "[tackle] resistance to a certain type of dominance" (9). The cultural manifestations that are being analyzed are all recent phenomena, connected to the socalled "Arab Spring" and the series of more or less successful revolutions that have shaken the region, leading to an "avalanche of popular cultural production" that is in "close connection with the street, its immediate reflection of people's sentiments on the ground as they unfold" (13).

While it is beyond the intentions of this short critique to discuss in detail each separate contribution, many of the studies presented in this volume make for stimulating reading, and the thematic division of the book itself is revealing of the approach of the authors. Part I, entitled "Popular Culture and the Aesthetics of Political Resistance", proposes three studies dealing with the Middle-Eastern music scene, be it in Israel/ Palestine or in the wider region, including émigré communities in Europe. Ted Swedenburg ("Palestinian Rap: Against the Struggle Paradigm"), examines the situation of Palestinian rap groups and their search for legitimacy, their "complicated political and cultural engagements" (22), dealing with diverse audiences, singing both in Arabic and Hebrew and needing to balance an avowedly militant content with artistic aspirations, while adapting the style of global hip hop to their particular needs 
and situations. Caroline Rooney ("Music Sans Frontières? Documentaries on Hip-Hop in the Holy Land and DIY Democracy") highlights the connection between Hip-Hop and "pro-democracy aspirations and liberation struggles" (33), seeing music as "a means to create possibilities of cultural empathy" (36) and to establish true lines of communication between Israelis and Palestinians. Finally, John A. Shoup ("Rai : North Africa's Music of the Working Class") presents this type of music as the true expression of the common people, able to maintain its identity even when sung in different languages, and resistant to any attempts to commercialize it, while faithful to its passion for social issues.

4 Part II, "Gender Politics, the Popular, Social Resistance", opens with a text by Dalia Said Mostafa ("Masculinity and Fatherhood within a Lebanese Muslim Community: Assad Fouladkar's When Maryam Spoke Out"), dealing with a 2002 Lebanese film in order to "address and analyze some theoretical questions about the relationship between masculinity and fatherhood as social and cultural constructs" (65). This allows the critic to comment on the persistence of patriarchal values within popular belief systems and to show how cinema can succeed in bringing to light "a number of taboo issues" (77). Walid El Khachab, in "Photo-Tattoo as Postmodern Veil : Photography and the Inscription of Subjectivity on the Female Body" discusses the fluctuating boundaries between high art and popular expression, bringing to the fore "postmodern concerns about female agency and the rejection of hegemonic cultural and patriarchal norms" (93) through art photography and the mixing of "popular references like tattoos, with elitist 'cultured' references" (80-81). Nadra Majeed Assaf ("Dancing Without My Body : Cultural Integration in the Middle East"), explores the domain of contemporary dance performance and the reactions to it, within countries where the body is "a forbidden issue" (95).

5 Part III, "Tradition and the Popular: New Forms and Trends", presents several reflections dealing with different media and different conceptions of what constitutes the "popular". Omaima Abou-Bakr ("Satellite Piety: Contemporary TV Islamic Programs in Egypt") presents an overview of Islamic talk /call in programs, particularly in Egypt, where a media that proves remarkably malleable to extremist Salafi discourse contributes to the creation of "a newly created Muslim public sphere" (123). This, of course, was before the recent counter-revolution that has seen the demise of the Morsi government and the instauration of a barely disguised military dictatorship ; it would be interesting to know about the more recent changes to Egypt's media landscape, following this sudden reversal of fortunes for the Muslim Brotherhood. Iren Ozgur (" Büşra : The Veiled Protagonist of a Comic Serial"), presents the rather surprising case of the comic character created in 2007 by Bahadir Boysal for the Turkish humour magazine Leman. This representation of a "smart and pious young woman", meant to be a positive depiction of conservative Muslims, opposed to the stereotypes generally portrayed in the popular press, and created by an admittedly secular author. Despite its numerous ambiguities, this work has known much success amongst the public, to the point of being adapted to the screen. Richard Jacquemond ("The Yacoubian Building and Its Sisters : Reflections on Readership and Written Culture in Modern Egypt") offers a portrayal of the evolving situation of the literary publishing market in the Arab world's biggest nation through an analysis of the publication and reception of a number of bestsellers, culminating in the "emergence of new kinds of editors-authors-publishers, booksellers, and readers as well" (145). Michael Frischkopf ("Tradition and Modernity: The Globalization of Sufi Music in Egypt") discusses the fate of Egyptian Sufi music in 
the throes of globalization and its vulnerability to technical and economic forces that drive a transformation from low-quality "authenticity" to high-fidelity recordings, produced in the West and adapted to foreign sensibilities and listening habits.

Part IV, "Cultural Hegemony : Popular representations of the Middle East and the US" starts with an article by John Carlos Rowe ("American Orientalism after Said"). In it, the critic evokes the work and career of the foremost modern student of the relationship between East and West in order to call for a greater engagement on the part of intellectuals to enlarge upon the spirit of his works, and to take responsibility for reshaping the public debate and reforming public education. Through several examples, both from the news and from TV fiction, the author formulates his "thesis of a neo-imperialism that works through the importation of international problems as part of a broader US globalization" (192), where the endgame is the creation of a new national identity out of reaction to several different competing and complementing Orientalisms. Ania A.M. Nashef ("Barbaric Space. Portrayal of Arab Lands in Hollywood Films") denounces the wilful reinforcement of misconceptions about Arab culture promoted by a number of recent movies, starting with Disney's Aladdin. The pictures of an inhospitable and desolate landscape, a series of repertoire images of uncouth and wild nomads, contribute to reinforce in western imagination "immature and uniformed representations" (201) that do nothing to advance the cause of mutual understanding. Maha El Said ("Alternating Images. Simulacra of Ideology in Egyptian Advertisements"), studies the way in which Egyptian youth's sense of self has been impacted by commercial advertisements promoting simulacra of principally American lifestyles and cultural forms. She ends her contribution optimistically by suggesting that "The Egyptian revolution of January 25,2011 [...] is a transformation from the hyper-real to the real, the end of the simulacrum of the postmodern condition into a new era that has yet to be named" (226). We now know that another era has already replaced the one that yet had to be named. Such are the dangers when discussing the cultural implications of recent, and still fluid, political events.

7 Part V, "Popular Culture and Revolution: The Voice of Dissent", is comprised of only two chapters. The first, "The Role of New Media in the Egyptian Revolution of 2011. Visuality as an agent of change", by Randa Aboubakr, makes a number of points about the "call for freedom of expression" (231) inherent in the revolutions of the Arab Spring, with a particular focus on Egypt. She comments on the role of social media, the Internet and the development of alternative means of disseminating information and communicating outside of the suffocating limits imposed by governments. The focus is on visual representations, seen as not just documents of events, but tools for change. Finally, the Editors, Walid El Hamamsy and Mounira Soliman ("The Aesthetics of Revolution. Popular Creativity and the Egyptian Spring") use Gramscian theory to discuss iconic representation of power during the Mubarak regime and its subversion through artistic production by the protesters of Tahrir Square. They conclude: "And just as the political situation is Egypt is still evolving so is the art still being shaped and reshaped in response to the events taking place." (257)

This book undoubtedly represents a very worthy endeavour, despite some terminological fluctuations as to its actual subject (does "popular" mean "representative of the working class" ?, or "folkish"”, or "traditional" ?, or "produced by the cultural industries" ?, or "dedicated to unbridled consumerism" ?, or "bestseller ?", or "the opposite of high art" ?, or all of the above and more at some time or 
another ?). From the perspective of researchers who have studied popular culture from a primarily French and francophone perspective, one cannot help but notice the disconnect between the authors' approaches and conclusions and those reached after the prolonged debates (in particular about the definition of the term "popular" or "mass" culture itself) that have taken place over the last thirty or so years, and that are not reflected in this volume. Indeed, the only French theoretical reference indicated in the Introduction's bibliography is Roland Barthes' Mythologies (1972), an important but by now rather dated work. This shows to what extent studies on the subject of mass culture would benefit from greater translation and dissemination of important critical texts that could prove useful in different cultural and linguistic contexts. Much work remains to be done in this regard. With this caveat, and despite the absence of a Conclusion that would have helped to try to bring together the many disparate trends of the various sections, this book provides an exciting and informative look into cultural productions that are generally ignored in the West, and represents a generous, although as yet only tentative, attempt at formulating the shape of an indigenous school of criticism.

\section{AUTHORS}

\section{VITTORIO FRIGERIO}

Dalhousie University 